aUniversidade do Estado do Rio de Janeiro, Instituto de Biologia, Pós-graduação em Biologia Vegetal, CEP 20550-013, Maracanã, Rio de Janeiro - RJ, Brazil.

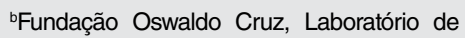
Produtos Naturais para Saúde Pública, Farmanguinhos, CEP 21041-250, Manguinhos, Rio de Janeiro - RJ, Brazil.

'Centro de Responsabilidade Socioambiental do Instituto de Pesquisas Jardim Botânico do Rio de Janeiro, CEP 22460-030, Jardim Botânico, Rio de Janeiro - RJ, Brazil.

*E-mail: davysonmoreira@hotmail.com

Recebido: 22 de Março de 2021

Aceito: 22 de Março de 2021

Publicado online: 29 de Setembro de 2021

\section{Study of volatile chemical constituents and insect-plant interaction in Piper mollicomum Kunth (Piperaceae) from Tijuca Forest, Rio de Janeiro - RJ, Brazil}

\author{
Estudo dos constituintes químicos voláteis e interação inseto-planta em Piper \\ mollicomum Kunth (Piperaceae) da Floresta da Tijuca, Rio de Janeiro - RJ, Brasil
}

Daniel de Brito Machado,a,b,c Ygor Jessé Ramos, ${ }^{a, b, c}$ George Azevedo de Queiroz, ${ }^{c}$ Anna Carina Antunes e Defaveri, ${ }^{c}$ Alexandra Aparecida Gobatto, ${ }^{c}$ Davyson de Lima Moreira ${ }^{b *}$ (D)

The aim of this work was to investigate the seasonal variation of essential oils (EOs) from leaves, inflorescences and infrutescences of Piper mollicomum Kunth and to identify which chemical and abiotic factors correlate with the frequency of visitation of their potential pollinators. The EOs were obtained by hydrodistillation in a modified Clevenger apparatus characterized and quantified by Gas Chromatography coupled to Mass Spectrometry (GC-MS) and by GC coupled to Flame Ionization Detector (GC-FID). Observations were made weekly, from October 2019 to February 2020, totaling $112.5 \mathrm{~h}$. The main compounds present in the EOs were identified as 1,8-cineole (16.22 to 36.66\%) and linalool (1.59 to $20.05 \%)$. Eupatoriochromene showed a distinction between leaves (0.81 to $3.66 \%)$ and reproductive parts ( 16.57 to $64.35 \%)$. The weekly observations revealed a high frequency of bee visits, and the results related to Spearman's correlation (potential pollinators versus major constituents) showed a strong positive correlation between constant insect visits and percentage of linalool and $E$-nerolidol in the inflorescences, in addition to negative correlation with germacrene D. A strong negative correlation was observed between humidity and the frequency of bee visits.

Keywords: Chemical ecology; pollination; bees; chromenes; terpenoids

\section{Introduction}

Studies show that $87.5 \%$ of plants, especially angiosperms, at some stages of their life cycle are dependent on pollination by animals. ${ }^{1}$ These studies denote the importance of pollination in natural ecosystems for promoting their stability. Therefore, the conservation, defense and protection of the main pollinators are essential for biodiversity maintenece. ${ }^{2}$ The symbiotic association between plants and pollinators has existed for millions of years, a fact that enabled an evolutionary advantage between angiosperms over all other pre-existing plant groups. ${ }^{3}$

Besides ecological interactions, different ecosystem incomes generate billions of dollars annually for the world economy. Pollination process is a considerable character in the economic growth originated by ecological task, with an estimated value of approximately 200 billion dollars. ${ }^{4,5}$

Among the different pollinators, bees are insects that play a prominent role in the genetic variability and reproduction of different plants in natural environments. ${ }^{6-8}$ They are equally important for agribusiness, as they can detect viable pollen grains that will facilitate the availability of seeds fertile in cultivated fields. ${ }^{9,10} \mathrm{Few}$ years ago, little quests emphasized the mutualistic interaction between angiosperms and bees, with researchers predominantly carried out by biologists, with only an observational point of view, without any purpose of evaluating their ecological role. ${ }^{11}$ However, recent studies have demonstrated the relevance of ecological interaction between angiosperms and bees, especially considering analyzes for improving habitat management and conservation strategies in forests that have suffered anthropogenic impacts. ${ }^{12-14}$ Approaches with pioneer species, such as some of Piperaceae family, may be considered attractive in the level for contribution to these analyzes.

Piper mollicomum Kunth is a pioneer species of the Piperaceae family, heliophile, that grows predominantly in places exposed to high light or in humid and dusky environments. 
It is characterized by membranous and tomentose leaves; inflorescences which are mostly curved and yellow when ripe. ${ }^{15}$ Specimens of this plant have been registered in several regions of Brazil, such as in the North (Amazonas, Rondônia and Tocantins); Northeast (Alagoas, Bahia, Ceará, Paraíba and Pernambuco); Midwest (Federal District, Goiás, Mato Grosso do Sul and Mato Grosso); Southeast (Espírito Santo, Minas Gerais, Rio de Janeiro, and São Paulo) and South (Paraná, Rio Grande do Sul and Santa Catarina). ${ }^{15}$ P. mollicomum is one of the many species of the genus Piper that are endemic to Brazil, with different popular names such as Aperta-ruão, Jaborandi, Jaborandi-manso, Pariparoba and Rabo-de-galo. ${ }^{16,17}$

Since the $19^{\text {th }}$ century, the therapeutic effects of $P$. mollicomum have been investigated. Its fruits were used to treat intestinal disorders, sexually transmitted infections and as anesthetics. ${ }^{18}$ Other activities from different organs of this plant (leaves, stems and even roots) are mentioned, ${ }^{19}$ such as antifungal, ${ }^{20}$ antibacterial, ${ }^{21}$ antinociceptive, ${ }^{22}$ antihepatotoxic effects, for low back pain relief, decreased extreme menstrual flow, and even as a hair tonic. ${ }^{23-25}$ However, there are few chemical-ecological approaches to this species. It is also known that essential oils (EOs) are involved in attracting pollinators. ${ }^{26,27}$ Terpenes are the main secondary metabolites present in the EOs of P. mollicomum that are precursors of different cosmetic and phytotherapeutic products, such as linalool, 1,8-cineole, camphor and $\beta$-ocimene. ${ }^{28,29}$

Thus, this research aims to verify which chemical phenotypes are present in the EOs of different organs (leaves, inflorescences and infrutescences) of P. mollicomum from a fragment of the Atlantic Forest of the State of Rio de Janeiro. In addition, we analyze possible correlations between abiotic factors and which different classes of volatile constituents of the EOs may influence the frequency of visitation of potential pollinators of this plant.

\section{Methodology}

\subsection{Study area and species}

The study area for investigation was in the Tijuca National Park (43'14'29,64”'W, $22^{\circ} 58^{\prime} 9,80^{\prime \prime}$ 'S), at an elevation ranging from $127 \mathrm{~m}$ to $68 \mathrm{~m}$ among the studied specimens. The region, located in the South Zone of the City of Rio de Janeiro, has a tropical monsoon climate according to the Köppen-Geiger classification. ${ }^{30}$ The climate shows at least one well-defined dry month with precipitation less than $60 \mathrm{~mm}$, but equivalent to more than $4 \%$ of total annual rainfall. Population of adult specimens of P. mollicomum with an average height of $1.65 \mathrm{~m}$ in an open area was investigated. The surroundings of the experimental plot consisted of a strip of native vegetation. The fertile species of $P$. mollicomum was previously identified by the taxonomist George Azevedo de Queiroz at the Botanical Garden of Rio de Janeiro (Rio de Janeiro, Brazil) and the voucher samples were deposited at the Herbarium RB (voucher n. RB01319727).

\subsection{Climatic data}

Data on abiotic factors were obtained from the Brazilian Meteorological Institute (INMET) as average temperature $\left({ }^{\circ} \mathrm{C}\right)$, radiation $\left(\mathrm{KJm}^{-2}\right)$, wind speed $(\mathrm{m} / \mathrm{s})$, rainfall $(\mathrm{mm})$ and humidity (\%). Data were obtained to the city of Rio de Janeiro and to the days of collection, from October of 2019 to February of 2020.

\subsection{Qualification of reproductive and vegetative phenology}

Weekly observation from October 2019 to February 2020 were done to qualify the phenological pattern of reproductive and vegetative parts of six subjects of $P$. mollicomum. Phenological events were evaluated as follows: leaf sprouting (emissions of leaf vegetative buds); leaf fall (reduction of leaves on stems and branches); immature or bud inflorescences (emission of green or yellow inflorescences, without the presence of pollen, with closed bracts); mature inflorescences (flowers in anthesis with the presence of pollen); immature or green infructescences (a process that ranges from the oxidation of mature inflorescences to the presence of infructescences with hardened pericarps); mature infructescences (infructescences with softened pericarps or with signs of predation). Thus, due to the small size of the flowers and fruits, a manual lens (60x magnification) was used to observe the inflorescences and infructescences in the field and to determine when the flowers were in the anthesis and stage of maturity, respectively. ${ }^{31}$

Fournier Intensity methodology was used to quantify the phenophases mentioned above, ${ }^{32}$ which is a quantitative method to estimate the phenological pattern of plant specimens. The Fournier Intensity consists in the formation of a scale that groups the phenological patterns analyzed in the plant, according to the criteria: 0 - Absence of the investigated phenophase; 1 - Presence of the investigated phenophase in a proportion of $1-25 \% ; 2$ - Presence of the investigated phenophase in a proportion of $26-50 \% ; 3$ Presence of the investigated phenophase in a proportion of $51-75 \% ; 4$ - Presence of the investigated phenophase in a proportion of $76-100 \%$.

\subsection{Observation of floral visitors}

Observations were made weekly from October of 2019 to February of 2020, from 8:00 a.m. to 5:00 p.m. (30 min observation and $30 \mathrm{~min}$ of resting, totaling $112.5 \mathrm{~h}$, to check the visiting insects. ${ }^{33}$ The insects that visited the inflorescences of $P$. mollicomum were photographically registered (exception for visitor 7) and collected with the aid of an entomological forceps-plume, with approximately $35 \mathrm{~cm}$ in diameter of the basket, $80 \mathrm{~cm}$ in depth, reach of $3 \mathrm{~m}$ and $12 \mathrm{~mm}$ of mesh. Visitors were promptly anesthetized in flasks that included cotton slightly moistened with $70 \%$ hydroalcoholic solution $(\mathrm{v} / \mathrm{v})$, and then, for the preservation of the samples, were placed in individual wrappers containing the same alcohol solution. ${ }^{34}$ 
The frequency and visiting hours of the insects, as well as their respective habits, behaviors, and activities, were recorded weekly during this period by direct observations and photographs in the field (Figure 1). Visitor 7 was registered in poor quality images and by this was omitted of this manuscript. Even so, it was captured and send for identification.

\subsection{Collection of plant material and essential oils (EOs) obtention}

Leaves $(150 \mathrm{~g})$, inflorescences $(40 \mathrm{~g})$ and infructescences $(40 \mathrm{~g})$ were collected from three specimens once for each month in the reproductive period, always on the day 15 of the months of October of 2019 to February of 2020, in the morning, between 9:00 a.m. and 10:00 a.m. These plant materials were manually reduced with scissors and submitted to the hydrodistillation method in a modified Clevenger type apparatus. ${ }^{35}$ The crushed material was transferred to a $2 \mathrm{~L}$ round bottom flask, in which $700 \mathrm{~mL}$ of distilled water were added. The hydrodistillation process was carried out for $2 \mathrm{~h}$. After completion of the process, the pure EOs were separated from the aqueous phase, subjected to drying with anhydrous sodium sulfate (Sigma-Aldrich, Brazil) and stored in a closed dark amber vial, and in a freezer at $-20^{\circ} \mathrm{C}$, until the time of analysis. The yields were calculated by the volume ratio in milliliters of EOs and the weight in grams of the fresh plant material used in the extraction multiplied by one hundred (percentage content $\mathrm{w} / \mathrm{v}$ ). ${ }^{36}$

\subsection{Essential oils (EOs) analysis}

The EOs obtained by hydrodistillation were subsequently solubilized in dichloromethane (HPLC grade, Tedia, Brazil), to obtain the final concentration of about $1000 \mathrm{ppm}$, and then subjected to analysis by Gas Chromatography coupled to Mass Spectrometry (GC- MS), in HP Agilent GC 6890 - MS 5973 equipment, for mass spectra to identify the compounds.

For quantitative parameters of the EOs, and, consequent calculation of the Retention Index (RI), analyzes were carried out by Gas Chromatography Coupled to the Flame Ionization Detector (GC-FID), on HP-Agilent 6890 equipment.

The conditions used by GC-MS were as follows: HP5MS column ( $30 \mathrm{~m} \times 0.25 \mathrm{~mm}$ id $\times 0.25 \mu \mathrm{m}$ film thickness), temperature ramp from $60{ }^{\circ} \mathrm{C}$ to $240{ }^{\circ} \mathrm{C}$ with increment of $3{ }^{\circ} \mathrm{C} / \mathrm{min}$, and with Helium (99.99\%) as carrier gas at constant flow rate of $1.0 \mathrm{~mL} / \mathrm{min}$ with mass range $\mathrm{m} / z 40$ - 600 atomic mass units (u), with impact energy of $70 \mathrm{eV}$ and operating in positive mode. A sample of $1 \mu \mathrm{L}$ of the EOs solution was injected, with an injector temperature of $270{ }^{\circ} \mathrm{C}$, splitless. ${ }^{37-38}$

GC-FID analyzes were performed using an HP-Agilent 6890 chromatograph, equipped with an HP-5MS capillary column ( $30 \mathrm{~m} \times 0.25 \mathrm{~mm}$ id $\times 0.25 \mu \mathrm{m}$ film thickness), temperature programming from $60{ }^{\circ} \mathrm{C}$ to $240{ }^{\circ} \mathrm{C}$, with an increase of $3{ }^{\circ} \mathrm{C} / \mathrm{min}$, using hydrogen as the carrier gas at a constant flow rate of $1.0 \mathrm{~mL} / \mathrm{min}$. The EOs solution was injected at $1 \mu \mathrm{L}$, with an injector temperature of $270{ }^{\circ} \mathrm{C}$, splitless. Retention times (Rt) were measured in minutes without correction..$^{37-38}$

RIs were calculated using data obtained by GC-FID from a homologous series of saturated aliphatic hydrocarbons $\left(\mathrm{C}_{8}-\mathrm{C}_{28}\right.$, Sigma-Aldrich, Brazil) performed on the same column and conditions used in GC-FID analysis..$^{39}$ The identification of the compounds was made by comparing the mass spectra obtained with the spectra of the databases (WILEY7 $n$; NIST), and with findings in the literature records. The comparison of calculated RIs with those from literature records was used to assist in the identification. ${ }^{40}$ All experiments were done in triplicate.

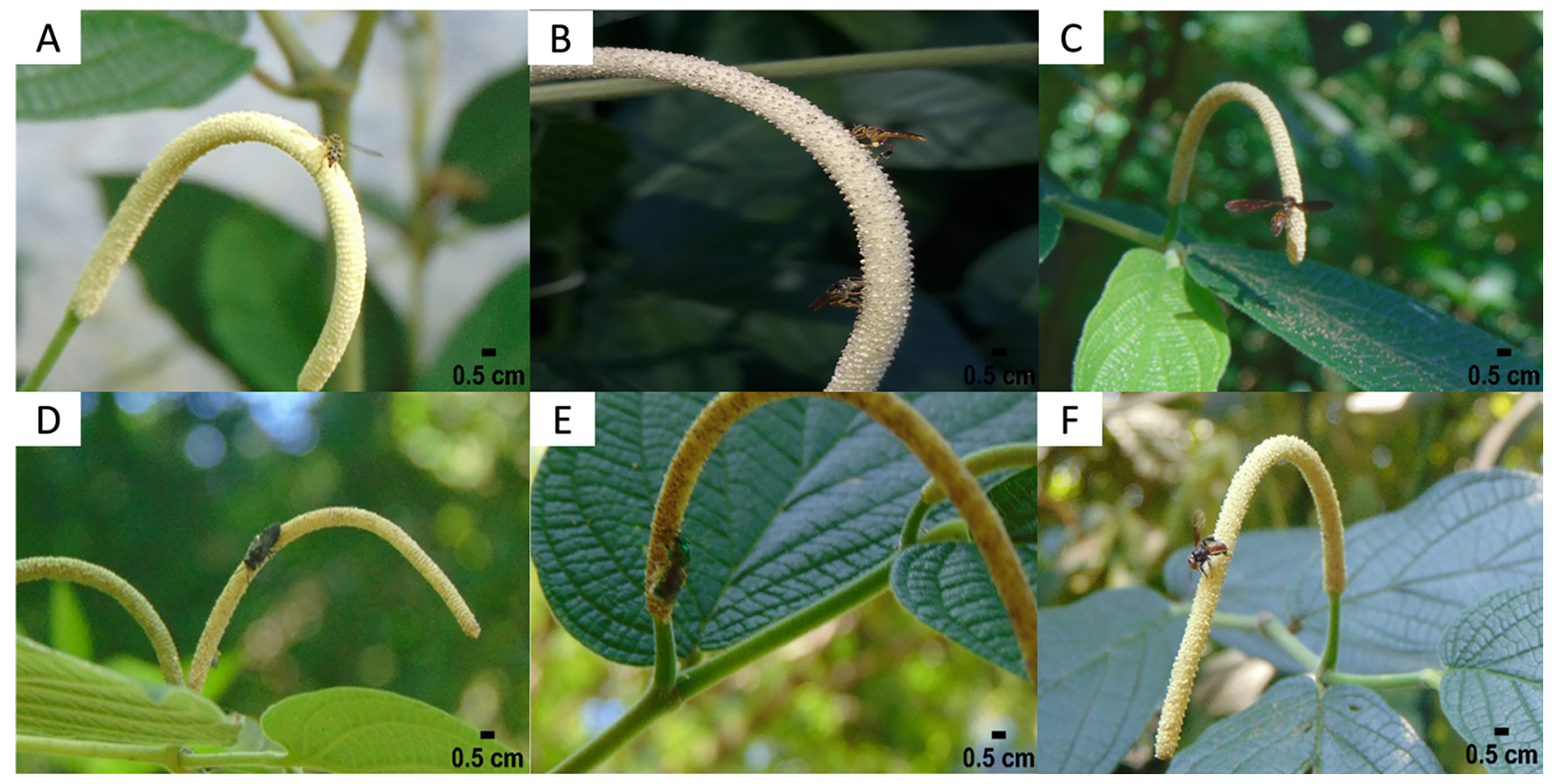

Figure 1. Main visitors of the inflorescences and infructescences of Piper mollicomum Kunth from Tijuca Forest/ RJ. The observations were made weekly from October 2019 to February 2020. A) - Insect 1; (B) - Insect 2; (C) - Insect 3; (D) - Insect 4; (E) - Insect 5; (F) - Insect 6 


\subsection{Statistical analysis}

Statistical analyzes were performed using the software Statistica version 10 (StartSoft Inc., Tulsa, USA). Spearman's correlation test was approached to access the correlation between abiotic factors (humidity, temperature, wind speed and precipitation), volatile constituents, and frequency of visitation of potential pollinators. The correlation coefficient can be positive (directly proportional) or negative (inversely proportional), assimilating quantitative values that suggest that the relationship between two or more variables is strong, moderate or weak such as 0.00 to 0.19 (very weak); 0.20 to 0.39 (weak); 0.40 to 0.69 (moderate); 0.70 to 0.89 (strong); 0.90 to 1.00 (very strong). For chemometric analyzes, including principal component analysis (PCA), they were used to assess the variance between EOs at different times of collection and plant parts.

\section{Results}

The chemical composition of the EOs of the vegetative parts of $P$. mollicomum was evaluated from October of 2019 to February of 2020. The results are shown in Table 1. The EOs showed great variations in their yields, ranging from 0.55 to $6.12 \%$. The leaves showed the lowest percentages of yield $(0.55$ to $0.69 \%$ ), and the infructescences the highest (3.45 to $6.12 \%$ ).

It was possible to identify 61 different compounds in the EOs from $P$. mollicomum. EO from inflorescences revealed the greatest variability of constituents $(n=46)$ in February. The EO from leaves, inflorescences and infructescences were evaluated chemically from November to February and did not show variations in their volatile constituents, demonstrating a rich and varied fraction in non-oxygenated sesquiterpenes.
However, the oxygenated monoterpenes 1,8-cineole (16.22 to $36.66 \%$ ) and linalool (1.59 to $20.05 \%$ ) provided prominent percentages in comparison to the other compounds. Nonoxygenated monoterpenes also showed relevant percentages (above $5 \%$ ), with the majority being $\alpha$-pinene $(0.72$ to $10.73 \%$ ) and $\beta$-pinene ( 0.70 to $8.84 \%$ ).

It is noteworthy that the compound desmethylencecalin (eupatoriochromene) showed a great distinction in the percentage content between leaves $(0.81$ to $5.13 \%)$ and reproductive parts (16.57 to $64.1 \%$ ).

Figure 1 shows the photographic record of the main visitors of the inflorescences of $P$. mollicomum that were observed during the reproductive phase (exception for visitor 7).

Table 2 shows the attendance of potential pollinators of $P$. mollicomum, together with data on the meteorological averages of the days on which the frequency of visitation was observed. Bees and flies were the groups of floral visitors observed on all inspection days. Hymenopterans were the most perceived insects in the inflorescences of $P$. mollicomum with a high frequency of visitation in practically all observed periods. Insect 2 registered the highest frequency of visits $(n=1033)$ of all floral visitors. Another bee, insect 6 , was the second hymenopteran with the highest number of visits $(\mathrm{n}=305)$. Two other bees, insects 5 and 4 , provided frequencies of 133 and 57, respectively. The diptera (insects 3 and 1) also registered relevant visit rates in the mature inflorescences of the studied specimens $(n=128$ and 33, respectively). Insect 7 was the least in visitation $(n=17)$.

The principal component analysis (PCA) was applied to the data obtained from the EOs of the 14 leaf samples, inflorescences and infructescences, and are shown in Figure 2. It was possible to record a total variation of $88.70 \%$ with the contribution of the first main component (PC1) of $63.00 \%$ and $26.70 \%$ for the second main component (PC2).

Table 1. Major chemical constituents of the essential oils from leaves, inflorescences and infructescences of Piper mollicomum Kunth from Tijuca Forest / RJ, in the months of October of 2019 to February of 2020

\begin{tabular}{|c|c|c|c|c|c|c|c|c|c|c|c|c|c|c|c|c|c|}
\hline \multirow{3}{*}{$\begin{array}{l}\text { Chemical } \\
\text { class }\end{array}$} & \multirow{3}{*}{ Compound $^{\mathbf{a}}$} & \multirow{3}{*}{$\mathbf{R I}_{\text {Cal }}$} & \multirow{3}{*}{$\mathbf{R I}_{\text {Lit }}$} & \multicolumn{14}{|c|}{ Relative peak area $(\%)$} \\
\hline & & & & \multicolumn{2}{|c|}{ October } & \multicolumn{3}{|c|}{ November } & \multicolumn{3}{|c|}{ December } & \multicolumn{3}{|c|}{ January } & \multicolumn{3}{|c|}{ February } \\
\hline & & & & IFL & $\mathbf{L}$ & IFL & $\mathbf{L}$ & IFR & IFL & $\mathbf{L}$ & IFR & IFL & $\mathbf{L}$ & IFR & IFL & $\mathbf{L}$ & IFR \\
\hline NOM & $\alpha$-pinene & 938 & 939 & 10.00 & 10.73 & 7.51 & 5.44 & 7.26 & 7.22 & 9.56 & 7.61 & 1.92 & 6.74 & 0.72 & 6.13 & 7.28 & 7.28 \\
\hline NOM & $\beta$-pinene & 979 & 980 & 8.40 & 8.84 & 5.75 & 4.76 & 5.36 & 5.63 & 7.12 & 5.50 & 2.06 & 5.97 & 0.70 & 4.90 & 6.03 & 3.48 \\
\hline OM & 1,8 - cineole & 1034 & 1033 & 17.00 & 17.28 & 23.00 & 16.22 & 22.70 & 23.00 & 26.32 & 25.90 & 5.75 & 36.66 & 2.57 & 17.70 & 19.54 & 19.70 \\
\hline $\mathrm{OM}$ & $\alpha$-terpineol & 1190 & 1189 & 0.20 & 0.23 & 4.01 & 5.66 & 6.16 & 0.29 & 4.34 & 0.31 & 1.19 & 6.19 & - & 3.28 & 3.53 & 3.97 \\
\hline OM & linalool & 1196 & 1198 & 2.90 & 3.04 & 14.00 & 7.96 & 14.60 & 15.10 & 9.11 & 15.80 & 7.10 & 15.52 & - & 20.50 & 1.59 & 8.52 \\
\hline NOS & germacrene D & 1477 & 1480 & 10.00 & 9.91 & 0.19 & 4.13 & - & 0.19 & 3.21 & - & 0.31 & 0.63 & - & 0.95 & 11.06 & 0.31 \\
\hline NOS & bicyclogermacrene & 1496 & 1500 & 5.70 & 5.43 & - & 5.03 & - & - & 3.63 & - & - & 1.01 & - & - & - & - \\
\hline OS & $E$-nerolidol & 1561 & 1564 & 5.10 & 4.70 & 5.16 & 6.72 & 4.43 & 5.06 & 5.63 & 3.95 & 9.06 & 5.43 & 10.40 & 9.97 & 3.77 & 3.34 \\
\hline \multirow[t]{2}{*}{$\mathrm{OC}$} & eupatoriochromene & 1743 & 1761 & 2.00 & 1.83 & 16.60 & 3.66 & 16.80 & 17.40 & 2.63 & 15.80 & 36.30 & 5.13 & 64.10 & 12.20 & 0.81 & 7.15 \\
\hline & Yield (\%) & & & 2.20 & 0.66 & 3.76 & 0.55 & 6.12 & 2.05 & 0.69 & 3.45 & 2.05 & 0.59 & 3.24 & 2.06 & 0.88 & 3.67 \\
\hline \multicolumn{4}{|c|}{ Identified Compounds (n) } & 43 & 44 & 28 & 47 & 23 & 28 & 43 & 23 & 46 & 40 & 17 & 30 & 40 & 35 \\
\hline \multicolumn{4}{|c|}{ Identified Compounds (\%) } & 98.61 & 97.16 & 98.86 & 96.86 & 98.97 & 99.03 & 98.72 & 99.72 & 98.68 & 98.31 & 100 & 99.98 & 98.74 & 99.81 \\
\hline
\end{tabular}

$\mathrm{RI}_{\mathrm{cal}}=$ Calculated retention index (column HP-5MS); $\mathrm{RI}_{\mathrm{lit}}=$ Literature retention index ${ }^{39}$; ${ }^{a}$ All compounds were identified by MS and RI according to experimental; IFL - Inflorescences; L - Leaves; IFR - Infructescence; NOM - Non-oxygenated monoterpenes; OM - Oxygenated Monoterpenes; NOS Non-oxygenated sesquiterpenes; OS - Oxygenated Sesquiterpenes; OC - Other Compounds 
Table 2. Frequency of visitation of potential pollinators and averages of the phenological events of Piper mollicomum Kunth in the Tijuca Forest/ RJ, in the weeks from October of 2019 to February of 2020

\begin{tabular}{|c|c|c|c|c|c|c|c|c|c|c|c|c|c|}
\hline \multirow{3}{*}{ Week } & \multicolumn{7}{|c|}{ Visitation frequency $(\Sigma d)$} & \multicolumn{6}{|c|}{ Phenophases (Average) } \\
\hline & \multicolumn{7}{|c|}{ Insect } & \multirow{2}{*}{$\mathbf{L R}$} & \multirow{2}{*}{$\mathbf{L F}$} & \multirow{2}{*}{ IFL - Mature } & \multirow{2}{*}{ IFL - Immature } & \multirow{2}{*}{ QT - IFL } & \multirow{2}{*}{ IFR } \\
\hline & 1 & 2 & 3 & 4 & 5 & 6 & 7 & & & & & & \\
\hline $31 / 10 / 2019$ & 16 & 0 & 0 & 0 & 0 & 0 & 0 & 1.50 & 0.00 & 1.00 & 4.00 & 3.50 & 0.00 \\
\hline $16 / 11 / 2019$ & 17 & 107 & 0 & 0 & 0 & 0 & 0 & 1.83 & 0.00 & 3.30 & 4.00 & 3.33 & 1.83 \\
\hline 29/11/2019 & 0 & 162 & 18 & 0 & 0 & 75 & 0 & 2.17 & 0.00 & 3.67 & 4.00 & 3.50 & 2.33 \\
\hline $17 / 12 / 2019$ & 0 & 140 & 0 & 8 & 46 & 88 & 0 & 2.33 & 0.00 & 3.67 & 3.33 & 3.83 & 2.67 \\
\hline 26/12/2019 & 0 & 154 & 0 & 9 & 38 & 129 & 0 & 2.50 & 0.00 & 3.33 & 3.17 & 3.50 & 3.17 \\
\hline $07 / 01 / 2020$ & 0 & 62 & 26 & 9 & 20 & 3 & 6 & 2.00 & 0.00 & 2.33 & 1.67 & 3.00 & 3.83 \\
\hline $18 / 01 / 2020$ & 0 & 65 & 16 & 8 & 0 & 3 & 3 & 2.83 & 0.00 & 1.67 & 1.50 & 2.17 & 4.00 \\
\hline $30 / 01 / 2020$ & 0 & 68 & 2 & 14 & 21 & 4 & 1 & 1.83 & 0.17 & 1.33 & 1.00 & 1.67 & 3.43 \\
\hline $03 / 02 / 2020$ & 0 & 53 & 11 & 9 & 8 & 3 & 7 & 1.67 & 0.67 & 0.83 & 0.33 & 0.83 & 4.00 \\
\hline $15 / 02 / 2020$ & 0 & 122 & 22 & 0 & 0 & 0 & 0 & 1.67 & 1.17 & 0.83 & 0.50 & 0.83 & 4.00 \\
\hline $22 / 02 / 2020$ & 0 & 100 & 33 & 0 & 0 & 0 & 0 & 2.67 & 1.50 & 0.83 & 0.50 & 0.83 & 3.67 \\
\hline Visits $\Sigma \mathbf{t}$ & 33 & 1033 & 128 & 57 & 133 & 305 & 17 & & & & & & \\
\hline
\end{tabular}

$\overline{\Sigma d}=$ Sum of the observation day; $\Sigma \mathrm{t}=$ Sum of the observation period (October of 2019 to February of 2020); IFL = Inflorescences, IFR = Infructescences; QT - Quantity; LR = Leaf release; LF = Leaf fall.

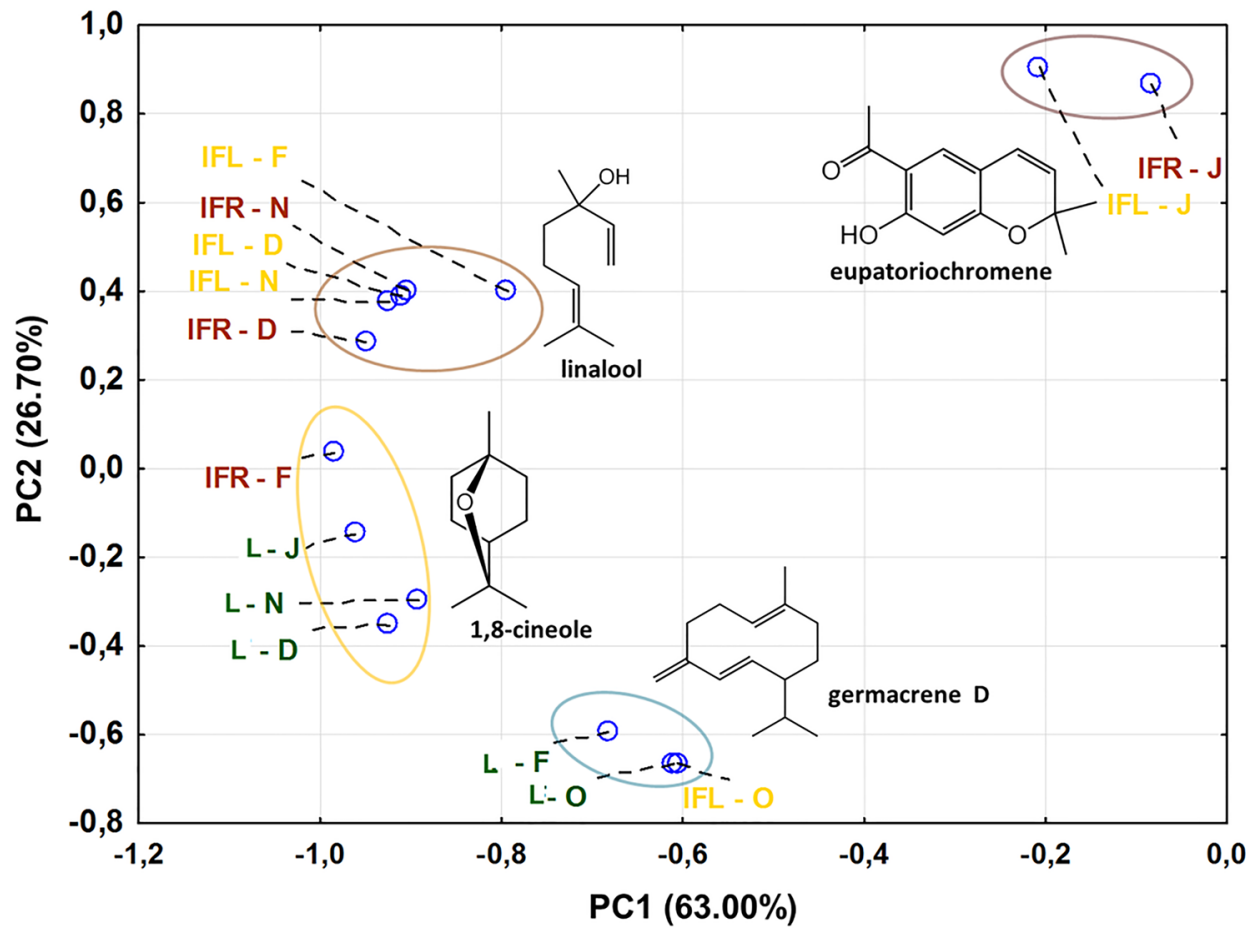

Figure 2. Biplot graph of principal component analysis based on 14 samples of essential oil of Piper mollicomum Kunth: leaves (L), inflorescences (IFL), infructescences (IFR). Collections performed during October of 2019 to February of 2020 in the Tijuca Forest in the city of Rio de Janeiro/ RJ

Four groups were registered with variations in the content of components: (1) Predominant in eupatoriochromene; (2) Predominant in linalool; (3) Predominant in 1,8-cineole; and (4) Predominant in germacrene D.

At the beginning of flowering in October, the leaves and inflorescences distanced themselves from the other groups due to the increased positive charge in $\mathrm{PC} 1$, influenced by the high levels of germacrene D (PC1: 2.12). This evidence corroborates the hypothesis that there is an allocation of leaf resources for inflorescences at the beginning of flowering.
This fact needs to be evaluated in a study on chemical ontogeny.

In the period of registration of the largest amounts of inflorescences in anthesis (mature), these presented higher percentage levels of linalool, and the leaves, higher percentage levels of 1,8-cineole. This record suggests that there is a biosynthetic dichotomy in the different organs of P. mollicomum that favors the transcription of the linalool synthase enzyme in the inflorescences and 1,8-cineole synthase in the leaves. 
In the period of equal predominance between inflorescences and infructescences, the percentage of eupatoriochromene increased, leading to the separation of IFR-J (Infructescences of the month of January) and IFL-J (Inflorescences of the month of January) from the others due to the increase in positive charge $\mathrm{PC} 2$ promoted by eupatoriochromene (PC2: 4.43). The decrease in the proportional relationship between these reproductive organs led to a reduction in eupatorichromene in the IFR-F (Infructescences of the month of February). This observation raises the hypothesis that eupatorichromene: A) has a signaling role in controlling IFL and IFR emission and B) herbivore protection for effective seed formation, thus ensuring their dispersion in P. mollicomum. These hypotheses must be investigated.

The results regarding the Spearman correlation $\left(r^{2}\right)$ between frequency of potential pollinators versus major constituents of essential oils of $P$. mollicomum are described in table 3 . The analyzes point to a strong positive correlation between the acyclic monoterpene linalool content and frequency of visitation of a species of bee (insect 2$),\left(r^{2}\right.$ $=0.900 ; p<0.05)$. The results also demonstrate a strong positive correlation between the sesquiterpene $E$-nerolidol percentage and constancy of visits to the infructescences by specimens of dipterans (insect 3$)\left(r^{2}=0.975 ; p<0.05\right)$. In an antagonistic way, the germacrene $\mathrm{D}$ sesquiterpene showed a negative correlation in relation to the visitation insect 6 (bee) $\left(r^{2}=-0.975 ; p<0.05\right)$.

Table 4 presents the results related to Spearman's correlation for potential pollinators versus pattern of phenological events. The data revealed a moderate positive correlation between the number of mature inflorescences and the frequency of bees' visitation (insect 7) $\left(r^{2}=0.650 ; p<0.05\right)$. It means that the greater the amounts of mature inflorescences, the greater the frequency of visitation 7 . However, the results also expressed a moderate negative correlation between the total amounts of inflorescences and the frequency of visitation of hymenopterans (insect 4$),\left(r^{2}=-0.635 ; p<0.05\right)$. Additional data must be obtained for further analysis and verification of these results.

The data also revealed positive and negative concomitant moderate correlations between frequency of bees' visitation and the number of infructescences (insect 4 and 2) $\left(r^{2}=\right.$ $0.610 ; p<0.05),\left(r^{2}=-0.667 ; p<0.05\right)$, respectively.

To investigate the possible influence of abiotic factors on insect visiting activity, Spearman's correlation test between the frequency of visitation of potential pollinators and environmental variables was performed. The results for these tests are shown in table 5. Our findings revealed a strong negative correlation between humidity and activity of bees visiting the inflorescences (insect 4 and insect 7), $\left(r^{2}=-0.806 ; p<0.05\right),\left(r^{2}=-0.642 ; p<0.05\right)$, respectively.

Tabela 3. Spearman's correlation between major constituents of reproductive parts and potential pollinators of Piper mollicomum Kunth of the Tijuca Forest/ RJ, from October of 2019 to February of 2020

\begin{tabular}{|c|c|c|c|c|c|c|c|}
\hline \multirow{3}{*}{ Compounds } & \multicolumn{7}{|c|}{ Spearman's correlation $\left(r^{2}\right)$} \\
\hline & \multicolumn{7}{|c|}{ Insect } \\
\hline & 1 & 2 & 3 & 4 & 5 & 6 & 7 \\
\hline$\alpha$-pinene & 0.783 & -0.300 & -0.718 & -0.872 & -0.667 & -0.200 & -0.894 \\
\hline$\beta$-pinene & 0.783 & -0.300 & -0.718 & -0.872 & -0.667 & -0.200 & -0.894 \\
\hline 1,8 -cineole & 0.112 & 0.800 & -0.359 & -0.205 & 0.205 & 0.700 & -0.670 \\
\hline linalool & -0.447 & $0.900^{*}$ & 0.462 & 0.205 & 0.410 & 0.400 & 0.112 \\
\hline$\alpha$-terpineol & 0.224 & 0.700 & 0.051 & -0.103 & 0.103 & 0.800 & -0.335 \\
\hline germacrene D & -0.057 & -0.616 & 0.132 & -0.237 & -0.395 & $-0.975^{*}$ & 0.229 \\
\hline bicyclogermacrene & 0.395 & -0.707 & -0.544 & -0.544 & -0.544 & -0.707 & -0.395 \\
\hline$E$-nerolidol & -0.224 & -0.100 & $0.975^{*}$ & 0.154 & -0.154 & -0.400 & 0.783 \\
\hline eupatoriochromene & -0.447 & 0.300 & 0.154 & 0.821 & 0.718 & 0.700 & 0.447 \\
\hline
\end{tabular}

Table 4. Spearman's correlation analysis between potential pollinators and pattern of phenological events of Piper mollicomum Kunth from Tijuca Forest/ RJ, from October of 2019 to February of 2020

\begin{tabular}{cccccccc}
\hline \multirow{2}{*}{ Insect } & \multicolumn{9}{c}{ Spearman's correlation $\left(\boldsymbol{r}^{2}\right)$} \\
\cline { 2 - 7 } & LR & LF & IFL-Mature & IFL - Immature & QT -IFL & IFR \\
\hline 1 & -0.461 & -0.344 & 0.068 & 0.600 & 0.288 & $-0.667^{*}$ \\
2 & 0.411 & -0.126 & 0.595 & 0.285 & 0.370 & -0.239 \\
3 & 0.217 & 0.528 & -0.417 & -0.541 & $-0.635^{*}$ & $0.610^{*}$ & -0.079 \\
4 & 0.092 & -0.045 & 0.047 & -0.357 & -0.070 & 0.323 & 0.015 \\
5 & 0.139 & -0.178 & 0.352 & 0.166 & 0.517 & -0.076 \\
6 & 0.415 & -0.408 & $0.650^{*}$ & -0.511 & -0.440 & $0.638^{*}$
\end{tabular}

$\mathrm{IFL}=$ Inflorescences; IFR = Infructescences; QT - Quantity; LR $=$ Leaf release; LF = Leaf Fall; ${ }^{*} p<0.05$. 
Table 5. Spearman's correlation analysis between environmental variables (abiotic factors) and potential pollinators of Piper mollicomum Kunth from Tijuca Forest/ RJ, from October of 2019 to February of 2020.

\begin{tabular}{cccccc}
\hline \multirow{2}{*}{ Insect } & \multicolumn{5}{c}{ Spearman's correlation $\left(r^{2}\right)$} \\
\cline { 2 - 6 } & Temperature $\left({ }^{\circ} \mathbf{C}\right)$ & Humidity $(\%)$ & Wind $(\mathbf{m} / \mathbf{s})$ & Rainfall $(\mathbf{m m})$ & Radiation $\left(\mathbf{k J} / \mathbf{m}^{2}\right)$ \\
\hline 1 & -0.121 & -0.081 & 0.378 & -0.337 & -0.040 \\
2 & -0.345 & 0.509 & 0.282 & 0.527 & 0.427 \\
3 & -0.084 & 0.340 & -0.423 & 0.209 & 0.442 \\
4 & 0.531 & $-0.806^{*}$ & -0.420 & -0.101 & -0.241 \\
5 & 0.575 & -0.525 & -0.079 & -0.203 & -0.134 \\
6 & 0.132 & -0.169 & 0.094 & 0.132 & -0.042 \\
7 & 0.179 & $-0.642 *$ & -0.495 & -0.232 & -0.347 \\
\hline
\end{tabular}

\section{Discussion}

The results regarding Spearman's correlation between major constituents of the inflorescences and potential pollinators of $P$. mollicomum revealed a strong positive correlation between the visit of bees to the inflorescences and the percentage content of linalool and $E$-nerolidol, in addition to a negative correlation between the content of germacrene D (tables 1 and 3). Data in the literature indicate the compound linalool as capable of assisting in the attraction of bees. In research carried out by Bergstrom and Teng $(1978)^{41}$, a significant content of this monoterpene was identified in the jaws of the hymenopterans belonging to the genus Colletes. Barros and collaborators (2009) $)^{42}$ found in studies involving specimens of Lippia alba (Mill.) NE Brown (Verbenaceae) that in periods when plants are exposed to high temperatures, they can lead to the volatilization of the linalool and boost the biosynthesis of cyclic monoterpenes such as camphor and 1,8-cineole. The results of this study demonstrated that when the percentage of camphor content in the vegetative parts of $P$. mollicomum decreases, the linalool content increases, which can be deduced, that in some way, the biosynthetic routes that synthesize these terpenes may be related. Studies also demonstrate that 1,8-cineole and linalool can assist in the pollination process by attracting bees ${ }^{43}$, which corroborates our findings that express a high content of these monoterpenes in the inflorescences, such as the high frequencies of hymenopteran visits to the reproductive parts of $P$. mollicomum. Blande and Glinwood $(2016)^{44}$ later indicated that linalool and 1,8-cineole are identified in high percentage amount in leaves of plant species when they are subjected to abiotic stress. In addition, other factors can be significant, such as the mechanism of operation of terpenes synthase and the stimuli arising from biotic and abiotic interactions. ${ }^{40,45}$

Previous studies on EO of the genus Piper of the Atlantic Forest had already revealed a significant content of E-nerolidol in $P$. aduncum L. ${ }^{46}$ and $P$. claussenianum (Miq.) C. DC. ${ }^{47-48}$ This compound is also widely used in the industry for the manufacture of drugs. ${ }^{49}$ Several therapeutic activities have already been presented by extracts of Piper species that demonstrated high percentages of $E$-nerolidol, such as leishmanicide for P. aduncum and P. claussenianum $^{50-51}$; and larvicidal action for P. gaudichaudianum Kunth ${ }^{52}$. However, no symbiotic activity between $E$-nerolidol and pollinators has yet been investigated in Piper. The positive correlation between visitation frequency of bees to the inflorescences of $P$. mollicomum suggests that this sesquiterpene, in addition to its protective function against herbivory, can act synergistically with other constituents of the EO to assist in pollinating attraction of insects. More experiments need to be done to confirm this hypothesis.

Our findings differ from studies involving a correlation between the constituent germacrene $\mathrm{D}$ and insect attraction. Mozuraitis and collaborators $(2002)^{53}$ demonstrated that these sesquiterpenes increase the attraction of pregnant females of moths of the species Chloridea virescens (Fabricius, 1777) and their subsequent oviposition in tobacco leaves. The same research pointed out that the attraction occurs by the connection of germacrene D to receptors present in the antennae of specimens of this moth, which would be related to the chemical message between plants and insects ${ }^{53}$. In another study that analyzed the EO of Vitis riparia Michx. (Vitaceae) grape leaves by GC, a considerable content of germacrene D was detected. In research carried out with Paralobesia viteana (Clemens, 1860) (insect that host of vines, called grape moth) and EO it has been shown that pregnant females of this insect species are attracted when EO containing germacrene D is emitted. ${ }^{54}$ The negative correlation between germacrene D and the attraction of possible pollinators in P. mollicomum, results of our study, may indicate that this sesquiterpene is synthesized to prevent the oviposition of moths or other pregnant insect females on the leaves. More accurate tests must be performed to confirm this hypothesis.

The chemical constituent eupatoriochromene has previously registered in significant percentage levels in EO from inflorescences and infructescences of other Piper species, such as $P$. gaudichaudianum Kunth and $P$. hostmannianum (Miq.) C. DC. ${ }^{55}$. Ramos and collaborators (2009) also identified the presence of some chromenes in the leaves of $P$. gaudichaudianum Kunth, which may exert negative pressure on the eggs of phytophagous caterpillars that prey on these specimens, thus inhibiting the development of these predators. ${ }^{56}$ 
Other works reported antifungal and antibacterial activity of some chromenes in P. chimonanthifolium Kunth. ${ }^{57}$ Another finding that demonstrates the protective role of eupatoriochromene identified an abnormality in the behavior of Colorado potato beetle (Leptinotarsa decemlineata Say, 1824) females that they fed on leaves that contained this chromene. The females of these Coleoptera that previously maintained active food, preying on the leaves of the plant, stopped feeding, buried themselves in the soil, and entered a state known as diapause. ${ }^{58}$ Some plants, such as Ageratum houstonianum Mill. (Asteraceae) accumulate chromenes (precocenes I and II), mainly in their leaves and flowers (12.45; 9.14 $\mathrm{pmol} / \mathrm{plant}$, respectively), to the detriment of other less predated parts such as stems and roots $(0.069 ; 0.63 \mathrm{pmol} / \mathrm{g}$ plant respectively), and this chromenes are stored in the mesophyll and not in the epidermis of plant tissues. ${ }^{59}$ These data corroborate our findings and allow us to infer that the presence of eupatoriochromene in the inflorescences and infructescences of $P$. mollicomum may be related to the protection of its reproductive organs.

The results obtained allow us to infer that the higher the humidity, the lower the visitation frequency of bees in the inflorescences of $P$. mollicomum (Table 5). These results corroborate with previous studies with other species that noticed a decrease in the number of visits between different groups of bees when the relative humidity rate increased. ${ }^{60-61}$ This fact was not registered only for rock fields, where the humidity of the air is relatively higher. Pedro (1992) ${ }^{62}$ found that the pollination activity of this group of hymenopterans (bees) on some flowers of plant specimens in the Cerrado is more prominent in periods when the humidity in this biome decreases.

\section{Conclusion}

The study of insect-plant interactions in Piper mollicomum, based on volatile components, allows us to conclude that the monoterpenes 1,8-cineole and linalool and the sesquiterpene $E$-nerolidol act as attractors of bees and that eupatoriochromene has the function of preventing herbivory, just as germacrene $\mathrm{D}$ works to repel potential predatory insects. In addition, the increase in air humidity decreases the frequency of bees visiting in the reproductive parts of $P$. mollicomum. Thus, we present a new contribution to the chemical-ecological understanding of the interrelationships of $P$. mollicomum with insects, a species of Piperaceae that is pioneer and fundamental for the recovery of devastated areas.

\section{Acknowledgements}

The authors thank CAPES, FAPERJ, PROEP-CNPq (407845/2017-8) for their financial support.

\section{References}

1. Ollerton, J.; Winfree, R.; Tarrant, S.; How Many Flowering Plants are Pollinated by Animals? Oikos 2011, 120, 321. [CrossRef]

2. Biesmeijer, J. C.; Roberts, S. P. M.; Reemer, M.; Ohlemüller, R.; Edwards, M.; Peeters, T.; Schaffers, A. P.; Potts, S. G.; Kleukers, R.; Thomas, C. D.; Settele, J.; Kunin, W. E.; Parallel Declines in Pollinators and Insect-pollinated Plants in Britain and the Netherlands. Science 2006, 313, 351. [CrossRef]

3. Soltis, P. S.; Soltis, D. E.; The origin and diversification of angiosperms. American Journal of Botany 2004, 91, 1614. [CrossRef]

4. Jordan, A.; Patch, H. M.; Grozinger, C. M.; Khanna, V.; Economic Dependence and Vulnerability of United States Agricultural Sector on Insect-Mediated Pollination Service. Environmental Science and Technology 2021, 55, 2253. [CrossRef]

5. Potts, S. G.; Biesmeijer, J. C.; Kremen, C.; Neumann, P.; Schweiger, O.; Kunin, W. E.; Global pollinator declines: trends, impacts and drivers. Trends in Ecology and Evolution 2010, 25, 345. [CrossRef]

6. Husband, B.; Schemske, D.; Evolution of the Magnitude and Timing of Inbreeding Depression in Plants Evolution, 1996, 50, 54. [CrossRef]

7. Kearns, C. A.; Inouye, D. W.; Waser, N. M.; Endangered Mutualisms: The Conservation of Plant-Pollinator Interactions. Annual Review of Ecology and Systematics 1998, 29, 83. [CrossRef]

8. Ashman, T.; Tiffany, M. K.; Janette, A. S.; Priyanga, A.; Martin, B.; Diane, R. C.; Michele, R. D.; Mark, O. J.; Susan, J. M.; Randall, J. M.; Martin, T. M.; William, G. W.; Pollen Limitation of Plant Reproduction: Ecological and Evolutionary Causes and Consequences. Ecology 2004, 85, 2408. [CrossRef]

9. Orr, M. C.; Hughes, A. C.; Chesters, D.; Pickering, J.; Zhu, C. D.; Ascher, J. S.; Global patterns and drivers of bee distribution. Current Biology, 2021, 31, 451. [CrossRef]

10. Kremen, C.; Williams, N. M.; Aizen, M. A.; Gemmill-Herren, B.; LeBuhn, G.; Minckley, R.; Packer, L.; Potts, S. G.; Roulston, T.; Steffan-Dewenter, I.; Vazquez, D. P.; Winfree, R.; Adams, L.; Crone, E. E.; Greenleaf, S. S.; Keitt, T. H.; Klein, A. M.; Regetz, J.; Ricketts, T. H.; Pollination and Other Ecosystem Services Produced by Mobile Organisms: A Conceptual Framework for the Effects of Land-use Change. Ecology Letters, 2007, 10, 299. [CrossRef]

11. Cockerell, T. D. A.; Descriptions of New Bees Collected by H. H. Smith in Brazil. Proceedings of the Academy of Natural Sciences of Philadelphia 1900, 1, 336. [Link]

12. Li, J.; Peng, W.; Wu, J.; An, J.; Guo, Z.; Tong, Y.; Huang, J.; Strawberry Pollination by Bombus lucorum and Apis mellifera in Greenhouses. Acta Entomologica Sinica 2006, 49, 342. [Link]

13. Velthuis, H. H. W.; Van Doorn, A.; A Century of Advances in Bumblebee Domestication and the Economic and Environmental Aspects of Its Commercialization for Pollination. Apidologie 2006, 37, 421. [CrossRef]

14. Palma, G.; Quezada-Euán, J. J. G.; Meltndez-Ramirez, V.; Irigoyen, J.; Valdovinos- Nuez, G. R.; Rejón, M.; Comparative Efficiency of Nannotrigona perilampoides, Bombus impatiens (Hymenoptera: Apoidea), and Mechanical Vibration on Fruit Production of Enclosed Habanero Pepper. Journal of Economic Entomology 2008, 101, 132. [CrossRef] 
15. Flora do Brasil. Piperaceae. Jardim Botânico do Rio de Janeiro, 2020. Disponível em: <http://floradobrasil.jbrj.gov.br> Acesso em: 12 março 2021.

16. Guimarães, E. F.; Giordano, L. C. S.; Piperaceae do nordeste brasileiro I: Estado do Ceará. Rodriguesia 2004, 55, 21. [CrossRef]

17. Guimarães, E. F.; Monteiro, D.; Piperaceae na reserva biológica de Poço das Antas, Silva Jardim, Rio de Janeiro, Brasil. Rodriguésia 2006, 57, 567. [CrossRef]

18. Peckolt, T.; Peckolt, G.; História das plantas medicinais e úteis do Brazil. Laemmert: Rio de Janeiro, 1888.

19. Potrich, F. B.; Potrich, F. B.; Baggio, C. H.; Freitas, C. S.; Mayer, B.; Santos, A. C., Twardowschy, A.; Marques, M. C. A.; Ação de extratos de plantas medicinais sobre a motilidade do trato gastrointestinal. Revista Brasileira de Plantas Medicinais 2014 . 16, 750. [CrossRef]

20. Lago, J. H. G.; Young, M. C. M.; Reigada, J. B.; Soares, M. G.; Roesler, B. P.; Kato, M. J.; Antifungal derivatives from Piper mollicomum and P. lhotzkyanum (Piperaceae). Química Nova 2007, 30, 1222 [CrossRef]

21. Duarte, M. C. T.; Leme, E. W.; Delarmelina, C.; Soares, A. A.; Figueira, G. M.; Sartoratto, A.; Activity of essential oils from Brazilian medicinal plants on Escherichia coli. Journal of Ethnopharmacology 2007, 111, 197. [CrossRef]

22. Souza, S. P.; Valverde, S. S.; Costa, N. F.; Calheiros, A. S.; Lima, K. S.; Frutuoso, V. S.; Lima, A. L.; Chemical composition and antinociceptive activity of the essential oil of Piper mollicomum and Piper rivinoides. Journal of Medicinal Plants Research 2014, 8, 788. [CrossRef]

23. Medeiros, M. F. T.; Senna-Vale, L.; Andreata, R. H. P.; MoraesValente, L. R. R.; Informacões estratégicas geradas através do estudo de patentes de plantas medicinais citadas pelos visitantes da Reserva Rio das pedras, Mangaratiba, Rio de Janeiro. Revista de Biologia Neotropical 2007, 4, 139. [CrossRef]

24. Brito, M. R.; Senna-Valle, L.; Plantas medicinais utilizadas na comunidade Caiçara da Praia do Sono, Paraty, Rio de Janeiro, Brasil. Acta Botânica Brasílica 2011, 25, 363.[CrossRef]

25. Messias, M. C. T. B.; Menegatto, M. F.; Prado, A. C. C.; Santos, B. R.; Guimarães, M. F. M.; Uso popular de plantas medicinais e perfil socioeconômico dos usuários: um estudo em área urbana em Ouro Preto, MG, Brasil. Revista Brasileira de Plantas Medicinais 2015, 17, 76. [CrossRef]

26. Usano-Alemany, J.; Herraiz-Peñalver, D.; Ecological Aspects of the Essential Oils from Different Salvia lavandulifolia Vahl Aerial Parts. Journal of Essential Oil Bearing Plants 2016, 19 , 1000. [CrossRef]

27. Robacker, D. C.; Erickson, E. H.; Floral Aroma: How Far Will Plants Go to Attract Pollinators? BioScience. 1988, 38, 390. [CrossRef]

28. Santos, P. R. D.; Moreira, D. L.; Guimarães, E. F.; Kaplan, M. A. C.; Essential oil analysis of 10 Piperaceae species from the Brazilian Atlantic forest. Phytochemistry 2001, 58, 547. [CrossRef]

29. Marques, A. M.; Barreto, L. S. A; Batista, M. E.; Curvelo, R. A. J.; Velozo, M. S. L.; Moreira, D. L.; Guimarães, F. E.; Soares, A. M. R.; Kaplan, C. A. M.; Chemistry and biological activity of essential oils from Piper claussenianum (Piperaceae). Natural Product Communications 2010, 5, 1837. [CrossRef]
30. Koppen, W; Geiger, G., C. Das geographisca System der Klimate, in: Handbuch der Klimatologie. Borntraeger 1936, 1, 1. [Link]

31. Valentin-Silva, A.; Staggemeier, V. G.; Batalha, M. A.; Guimarães, E.; What factors can influence the reproductive phenology of Neotropical Piper species (Piperaceae) in a semi-deciduous seasonal forest? Botany 2018, 96, 675. [CrossRef]

32. Fournier, L. A.; Un método cuantitativo para la medición de características fenológicas en árboles. Turrialba 1974, 24, 422. [Link]

33. Sakagami, S. F.; Laroca, S.; Moure, J. S.; Wild bee biocoenotics in São José dos Pinhais (PR), South Brazil. Journal of the Faculty of Science Hokkaido University Serie VI. Zoology 1967, 16, 253. [Link]

34. Polizel, A. L.; Nanya, S.; Conte, H.; Insetos dípteras como polinizadores em Orchidaceae. Revista Uningá 2015, 46, 11. [Link]

35. Akisue, G.;. Aparelho extrator de óleo essencial: modificação do aparelho de Clevenger. Revista Brasileira de Farmacognosia 1986, 1, 247. [CrossRef]

36. Ramos, Y. J.; Moreira, D. L.; Seasonal study of essential oil from aerial parts of Peperomia galioides Kunth (Piperaceae). Revista Virtual de Química 2019, 11, 1540. [CrossRef]

37. Oliveira, G. L.; Moreira, D. L.; Mendes, A. D. R.; Guimarães, E. F.; Figueiredo, L. S.; Kaplan, M. A. C.; Martins, E. R.; Growth study and essential oil analysis of Piper aduncum from two sites of Cerrado biome of Minas Gerais State, Brazil. Revista Brasileira de Farmacognosia 2013, 23, 743. [CrossRef]

38. Dool, H. V. D.; Kratz, P. D.; A generalization of retention index system including linear temperature programmed Gas-Liquid Partition Chromatogaphy. Journal of Chromatography 1963, 11, 463. [CrossRef]

39. Adams, R. P.; Identification of essential oil components by gas chromatography/mass spectroscopy, 1a ed., Allured Pub Corp: United States, 2009.

40. Ramos, Y. J.; Brito-Machado, D.; Queiroz, G. A.; Guimarães, E. F.; Defaveri, A. C. A.; Moreira, D.; Chemical composition of the essential oils of circadian rhythm and of different vegetative parts from Piper mollicomum Kunth-A medicinal plant from Brazil. Biochemical Systematics and Ecology 2020, 92, 104116. [CrossRef]

41. Bergström, G.; Tengö, J.; Linalool in mandibular gland secretion of Colletes bees (Hymenoptera: Apoidea). Journal of Chemical Ecology 1978, 4, 447. [CrossRef]

42. Barros, F.; Zambarda, E.; Heinzmann, B.; Variabilidade sazonal e biossíntese de terpenóides presentes no óleo essencial de Lippia alba (Mill.) n.e. brown (Verbenaceae). Química Nova 2009, 32, 861. [CrossRef]

43. Borg-Karlson, A. K.; Tengö, J.; Valterová, I.; Unelius, C. R.; Taghizadeh, T.; Tolasch, T.; Francke, W.; (S)-(+)-Linalool, a Mate Attractant Pheromone Component in the Bee Colletes cunicularius. Journal of Chemical Ecology 2003, 29, 1. [CrossRef]

44. Blande, J. D.; Glinwood, R. (eds.); Deciphering chemical language of plant communication, 1st ed., Springer: Switzerland, 2016. [CrossRef]

45. Singh, K.; Kaloni, D.; Sehgal, K.; Pan, S.; Sarethy, I. P.; Em Plant-derived Bioactives; Swamy, M. K., eds.; Springer nature: Singapore, 2020, chap. 2. [CrossRef] 
46. Chan, W. K.; Tan, L. T. H.; Chan, K. G.; Lee, L. H.; Goh, B. H.; Nerolidol: A Sesquiterpene Alcohol with Multi-Faceted Pharmacological and Biological Activities. Molecules 2016, 21, 529. [CrossRef]

47. Marques, A. M.; Barreto, A. L. S.; Curvelo, J. A. D. R.; Romanos, M. T. V.; Soares, R. M. D. A.; Kaplan, M. A. C.; Antileishmanial activity of nerolidol-rich essential oil from Piper claussenianum. Revista Brasileira de Farmacognosia 2011, 21, 908. [CrossRef]

48. Curvelo, J. A. R.; Marques, A. M.; Barreto, A. L. S.; Romanos, M. T. V.; Portela, M. B.; Kaplan, M. A. C.; Soares, R. M. A.; A novel nerolidol-rich essential oil from Piper claussenianum modulates Candida albicans biofilm. Journal of Medical Microbiology 2014, 63, 697. [CrossRef]

49. Simas, N. K.; Lima, E. C.; Conceição, R. S.; Kuster, R. M.; Filho, A. M. O.; Lage, C. L. S.; Produtos naturais para o controle da transmissão da dengue: atividade larvicida de Myroxylon balsamum (óleo vermelho) e de terpenóides e fenilpropanóides. Química Nova 2004, 27, 46. [CrossRef]

50. Ceole, L. F.; Cardoso, M. D.; Soares, M. J.; Nerolidol, the main constituent of Piper aduncum essential oil, has anti-Leishmania braziliensis activity. Parasitology 2017, 144, 1179.[CrossRef]

51. Marques, A. M.; Barreto, A. L. S.; Curvelo, J. A. D. R.; Romanos, M. T. V.; Soares, R. M. D. A.; Kaplan, M. A. C.; Antileishmanial activity of nerolidol-rich essential oil from Piper claussenianum. Revista Brasileira de Farmacognosia 2011, 21, 908. [CrossRef]

52. Sperotto, A. R. M.; Moura, D. J.; Péres, V. F.; Damasceno, F. C.; Caramão, E. B.; Henriques, J. A. P.; Saffi, J.; Cytotoxic mechanism of Piper gaudichaudianum Kunth essential oil and its major compound nerolidol. Food and Chemical Toxicology 2013, 57, 57. [CrossRef]

53. Mozuraitis, R.; Stranden, M; Ramirez, M. I.; Borg-Karson, A. K.; Mustaparta, H.; (-)-Germacrene D Increases Attraction and Oviposition by the Tobacco Budworm Moth Heliothis virescens. Chemical Senses 2002, 27, 505. [CrossRef]
54. Cha, D. H.; Nojima, S.; Hesler, S. P.; Zhang, A.; Linn, C. E.; Roelofs, W. L.; Loeb, G. M.; Identification and Field Evaluation of Grape Shoot Volatiles Attractive to Female Grape Berry Moth (Paralobesia viteana). Journal of Chemical Ecology 2008, 34, 1180. [CrossRef]

55. Morais, S. M.; Facundo, V. A.; Bertini, L. M.; Cavalcanti, E. S. B.; Anjos-Júnior, J. F.; Ferreira, S. A.; Souza-Neto, M. A.; Chemical composition and larvicidal activity of essential oils from Piper species. Biochemical Systematics and Ecology 2007, 35, 670. [CrossRef]

56. Ramos, C. S.; Vanin, S. A.; Kato, M. J.; Sequestration of prenylated benzoic acid and chromenes by Naupactus bipes (Coleoptera: Curculionidae) feeding on Piper gaudichaudianum (Piperaceae). Chemoecology 2009, 19, 73. [CrossRef]

57. Lago, J. H. G.; Ito, A. T.; Fernandes, C. M.; Young, M. C. M.; Kato, M. J.; Secondary metabolites isolated from Piper chimonantifoliumand their antifungal activity. Natural Product Research 2012, 26, 770. [CrossRef]

58. Denlinger, D. L. Why study diapause? Entomological Research 2008, 38, 1. [CrossRef]

59. Siebertz, R.; Proksch, P.; Witte, L.; Accumulation and biosynthesis of the chromenes precocene I and II in Ageratum houstonianum. Phytochemistry 1990, 29, 2135.[CrossRef]

60. Kleinert-Giovannini, A.; Imperatriz-Fonseca, V. L.; Flight Activity and Responses to Climatic Conditions of two Subspecies of Melipona marginata Lepeletier (Apidae, Meliponinae). Journal of Apicultural Research 1986, 25, 3. [CrossRef]

61. Antonini, Y.; Souza, H. G.; Jacobi, M. C.; Fábio, E. B.; Diversidade e Comportamento dos Insetos Visitantes Florais de Stachytarpheta glabra Cham. (Verbenaceae), em uma Área de Campo Ferruginoso, Ouro Preto, MG. Neotropical Entomology 2005, 34, 555. [CrossRef]

62. Pedro, S. R. M.; Dissertação de Mestrado, USP-Ribeirão Preto, 1992. [Link] 